\title{
BRECHT IN SPAIN
}

\section{Reinhold Grimm ${ }^{1}$}

Let me begin with a piece of personal publishing experience. In 1991, a slim monograph of mine entitled Ein iberischer "Gegenentwurf"? Antonio Buero Vallejo, Brecht und das moderne Welttheater ("An Iberian 'Counterconception'? Antonio Buero Vallejo, Brecht, and Modern World Theater") appeared in the Danish series Publications of the Department of Languages and Intercultural Studies [of the] University of Aalborg. ${ }^{2}$ Shortly thereafter, I read a paper titled "Brecht in Spanien" ("Brecht in Spain") at an international conference; it came out in Italian translation, as "Brecht in Spagna," in the Florence-based journal Rivista di Letterature moderne e comparate in $1992^{3}$ and was subsequently included, in its German original, in my volume Versuche zur europäischen Literatur ("Essays on European Literature") in 1994. ${ }^{4}$

Interestingly, at about the same time as I was preparing and penning my monograph and paper, the American Hispanist from Rutgers, Phyllis Zatlin, brought out an article in the yearbook Theatre History Studies - and its title, lo and behold, also

\footnotetext{
${ }^{1}$ University of California-Riverside

${ }^{2}$ Reinhold Girmm, Ein iberischer "Gegenentwurf"? Antonio Buero Vallejo, Brecht und das moderne Welttheater (Copenhagen/Munich, 1991.)

${ }^{3}$ Reinhold Grimm, "Brecht in Spagna," Rivista di Letterature moderne e comparate, N.S. 45 (1992) : 73-89.

${ }^{4}$ Renihold Grimm, Versuche zur europäischen Literatur (Berne [etc.], 1994) 213-32.
}

ran exactly "Brecht in Spain." ${ }^{5}$ Still, I think it ought to be self-evident that our contributions originated independently of each other, even though Zatlin's article was published as early as 1990, and even though I did have a last-minute chance to refer to it, if only briefly and, as it were, retroactively. ${ }^{6}$

Why am I reporting all this? For two reasons. First and foremost, because Zatlin's findings and my own amazingly coincide on a general, or historical, level, whereas they differ sharply on a specific, both aesthetic and dramaturgical, level that is most decisive; or to be more precise, the latter is entirely, and indeed sorely, missing in the Zatlin article, which otherwise is so thorough and convincing. Secondly, however, because none of my modest proposals at least as far as I have been able to ascertain seems as yet to have been noticed, much less received or discussed, by the international community of Brecht scholars. And what I here have in mind are not just the specialists, the countless Brechtians and Brechtologists, but their qualified colleagues, the comparatists and theater historians, as well.

Rest assured that I am not (or not primarily) concerned about the recognition of my work, I am more concerned with making sure that the phenomena in ques-

5 Phyllis Zatlin, "Brecht in Spain," Theatre History Studies 10 (1990) : 57-66.

${ }^{6}$ See Grimm, Ein iberischer "Gegenentwurf"? 78f., n. 32 
tion-i.e., the historical and the article facts and texts and ideas - be duly recognized. Hence, I believe it is justifiable, perhaps even mandatory, to return to the said twofold topic once more. In doing so, I shall begin with a summary of the first, or general, aspect, mainly relying, for the sake of convenience, on Zatlin's state-ments; then, I shall devote myself to the second, or specific, aspect which is so conspicuously absent from her consider-ations. A few concluding remarks, again of a more general nature, I hope will aptly round off, our fleeting survey.

Historically speaking, there are three major points regarding Brecht's influence over Spain on which Zathin and I agree. The same applies, needless to say, to the political background of this whole development. "Throughout the long Franco era... and even into the beginning of the democratic monarchy that followed," Zathin rightly observes,

Spanish theatre was subject to official censorship. Texts were carefully screened for their political, religious, and moral content. While censorship eased gradually over the years, until the early 1960 s it prohibited any major production of works by certain taboo dramatists, among them, Bertolt Brecht. [Indeed,] one could hardly expect a conservation government that forebade the staging of Spain's own Ramón del Valle-Inclán....and Federico Garcia Lorca... to allow the performance of plays by an avowed Marxist like Brecht. ${ }^{7}$

Only ten years before Franco's death in 1975 did the reversal suddenly take place. The initiative, not surprisingly, came from Catalonia, the heartland of Spanish socialism and anarchism. To wit: "The first staging in Spain with ticket sales to the general public and a virtually uncut Brecht text was a Catalan production of The Three penny Opera [in Barcelona]" (64; cf. also 58). This happened in early 1965 ; in March, the first Brecht production in castillano-once again in Bacelona followed. Admittedly success was limited, however, the subsequent stagings of Brecht's Mother Courage and Her Children and The Good Woman of Sezuan (in 1966 and 1967, respectively) proved so much the more impressive and successful. With them, the German playwright conquered, so to speak, the Spanish capital and, moreover, his Chiness - or pseudoChineses - parable play was awarded, the coveted prize for the best foreign drama of the year.

But let us turn to those three points I mentioned. (1) The reception of Bertolt Brecht in Spain actually occurred remarkably early, in spite of appearances; the spectacular reversal since 1965 had, in other words, long been in the making. As Zatlin states:

The fact that Brecht's theatre was officially prohibited in Spain prior to the mid-1960s does not... mean that Brecht was previously unknown south of the Pyrenees. The rapid

\footnotetext{
${ }^{7}$ Zatlin, "Brecht in Spain" 57. All further references to this article will appear in parentheses in the text.
} 
staging of his works once official censorship eased indicates that theatre professionals were eagerly waiting in the wings. (57)

And further:

By the early 1950s, spanish translations from Argentina of texts by and about Brecht were circulating in the university and intellectual community... French translations were even more readily available and were linguistically accessible to educated Spaniards, who had been required to study the language. (58)

In short, Brecht's dramatic oeuvre was not merely read and studied but virtually devoured by practitioners of the theater and by critics. As a matter of fact, one of them, the stage director Ricard Salvat, had lived in Germany for quite some time; not only was he familiar with the work of Brecht's Berliner Ensemble, he even knew Brecht personally. And the same holds true for the writer and editor José Monleón. The theatrical journal Primer Acto, founded by him in 1957, began early on to publish, alongside Brecht translations, numerous contributions dealing with Brecht and his oeuvre, and several of these were authored by the two leading dramatists and/or dramatic theoreticians of Spain: namely, Antonio Buero Vallejo and Alfonso Sastre. Nor was Primer Acto the sole Spanish journal to open its pages and columns to such Brechtian discussions or disquisitions. So, it stands to reason "that once Brecht finally received the official green light in Spain, the Spainsh stage was ready" (58).

(2) It must be reiterated and stressed that the German playwright's reception in
Madrid, as in Spain as a whole, was not only uncommonly successful and lasting but, in addition, unusually complete and nearly all-embracing. For the plays that were produced were in no way restricted to those famous dramas from Brecht's exile years-Mother Courage and The Good Woman, or The Caucasian Chalk Circle - but they also included pieces such as the one-act play The Wedding; the adaptation of Christopher Marlowe's Edward II, most Brechtianly titled Life of Edward the Second of England; the acrid political revue Fear and Misery of the Third Reich; and even the Hitler grotesquerie The Resistible Rise of Arturo $\mathrm{Ui}$, as well as the ever popular Three penny Opera. "By 1978," Zatlin had to confess, if somewhat reluctantly, "[a Spanish] theatre chronicler... felt justified in proclaiming that Brecht had become the most frequently staged dramatist in Spain" $(60)$. Nor was there any dearth of distinctions and honors either, ranging from the aforesaid prizes for the best foreign play (awarded several times) to various prized for excellence in directing and acting.

(3) It must likewise be emphasized that among those who turned to Brecht were, along with Spain's most renowned directors and critics and most celebrated actors and actresses, some of her most esteemed and distinguished writers, too. Mention has already been made of the indefatigable theorizer Sastre as well as of Buero Vallejo; now, however, we have to add no less a worthy than the novelist José Camilo Cela. He provided the stage version for the production of Arturo Ui, Buero, on the other hand, was responsible for the equally masterful rendition of Mother Courage and Her Children. "Buero doubtless took the most pains- 
taking and time-consuming approach," Zatlin informs us. "Fully aware that Brecht revised constantly," she goes on to explain,

he started with two different versions in German of Mother Courage and had a friend prepare literal translations of both. He then worked with a German-Spanish dictionary to resolve any lingering doubts. He spent six months on the version, about six times as long as he would normally have spent on a stage adaptation, but was pleased with the results, including the songs. His version was approved by Brecht's heirs. (65)

Yet what this fine rendition marked was not the Spaniard's initial encounter with the Brechtian masterpiece. On the contrary, as I eventually found out, his acquaintance ship, and instinctive fascination with Mother Courage has in fact sprung from the literary climate of the late 1940s. Granted that I, dependent exclusively on printed and secondhand sources, could merely infer and surmise such an early date while Zatlin, by contrast, was lucky enough to obtain her knowledge straight from the horse's mouths through being able to interview Buero. And what did he recall? Precisely "that he and other theatre people were excited about Mother Courage from the time of its production in East Berlin in 1949..." (58).

So much for the entente cordiale between Zatlin and myself. The remarks and propositions following constitute an attempt, however sketchy, at filling the gaping lacuna she left, and at evaluating and acknowledging that which Antonio Buero Vallejo, apart from his consummate translation, has really achieved over the years, indeed decades, through both his critical and creative dialogue with the German playwright Bertolt Brecht, the towering practitioner and theorist of a non-Aristotelian, epic theater of alienation.

What I mean can probably best and most quickly be illuminated by a simple quotation. In 1950, Buero's piece En la ardiente oscuridad (In the Burning Darkness) saw its world premiere in Madrid. This sombre drama, which is situated in an institute for the blind, among incurably blind people, contains a scene that inevitably leads up to the play's peripety and tragic catastrophe: namely, the last and ultimately fatal clash of its two protagonists, the young men Ignacio and Carlos. The latter has almost cheerfully reconciled himself to his fate, the former keeps on desperately revolting against it. Slightly abridged, the core of this scene reads in Marion Peter Holt's English version:

IGNACIO....I know that seers try at times to imagine our condition, and so they close their eyes. (The stage lights begin to dim.) Then they tremble at the horror of it....(The stage is totally dark. Only the stars are still shining through the window.) We are all immersed in the horror..., without knowing what it is! (Now the stars begin to go out.) And that's why it's doubly terrible for me. (Absolute darkness on the stage and in the theatre.) Only our voices cross in the darkness....

CARLOS. (With a suggestion of apprehension in his voice) Ignacio!

IGNACIO. Yes.... You've made a start. You're beginning to understand. (Brief pause) I've sensed how men with sight are happy with the return of 
light in the mornings. (The stars begin to shine again, as the stage lights slowly come up.) They move about identifying objects, enjoying their shapes and... their colors. They are filled with the joy of light, which is for them a real gift from God.... But for us it's all the same. Light can go and come back; it can draw forms and colors from the darkness; it can show an object in the completeness of its creation. (Now the lights are completely up again)... Yet for us it doesn't matter. We see nothing. ${ }^{8}$

The tremendous effectiveness as well as staginess of the lighting technique in this scene ought to be obvious and yet, Buero hasn't deigned to justify such overtly theatrical means in any way, either on rational or on naturalistic grounds which is all the more astonishing since otherwise (in terms of plot, character portrayal, set, etc.) he obediently complied with the rules of dramatic realism, aiming at psychological plausibility and lifelike depictions throughout. But it should be no less obvious, I think, that Buero's device can hardly be reduced to a cheap if most cleverly handled trick, nor even to a mere stage effect; clearly and undeniably, his use of light and darkness in En la ardiente oscuridad opens up additional and much deeper dimensions. For isn't the entire course of events, indeed the whole intellectual and emotional thrust of the play virtually condensed (verdichtet) in this extraordinary scenic invention, which one cannot but admire?

${ }^{8}$ Antonio Buero-Vallejo [sic], Three Plays: The Sleep of Reason [/] The Foundation [/] In the Burning Darkness. Trans. Marion Peter Holt (San Antonio, 1985) 169.
You will have already guessed, I suspect, what kind of role Brecht and his theatrical theory and practice - especially, both his concept of alienation, or Verfremdung, and his device of alienation, or Verfremdungseffekt came to play for the Spaniard and for his work as a modern dramatist. That essential and so impressive scene which I have quoted reveals itself as anything but an isolated case in Buero's extensive output that now comprises well over two dozen pieces; at least one quarter of these texts (or, as others claim, even more than half of them) proceed according to the same or a very similar pattern. The technical means may be totally different but their function remains identical in each and every instance. What solely matters for Buero is the forceful transplantation, from the stage into the house, of physical feelings (mainly defects and handicaps) and/or psychic ones (mainly sufferings and delusions); steadfastly, he strives "to make the audience experience [as intensely and as instantly as possible] his characters' blindness, deafness, hallucinations, or inner states of mind." 9 Such devices, which are unmistakably meant to induce the very opposite of Brechtian alienation that is to say, an uninhibited and virtually unrestrained from of empathy can also be found in the "Parable" (thus the subtitle) $E l$ concierto de San Ovidio (The Concert at Saint Ovide) of 1962, in the "Experiment" El tragaluz (The Basement Window) of 1967 , and, most notably, in the "Fantasia in Two Parts" El sueño de la razón (The

${ }^{9}$ Cf. Phyllis Zatlin [-Borings], "Expressionism in the Contemporary Spanish Theatre," Modern Drama 26 (1983) : 555-69. Of course, Zatlin is fully aware of Buero Vallejo's importance; what she seems to be unaware of is, however, his truly dialectical relationship to Bertol Brecht. 
Sleep of Reason) of 1970, the drama delving into the 76-year-old painter Goya who has lost his hearing, arguably Buero's weightiest and surely his most typical play; furthermore, they can be spotted in the two "Fables" Llegada de los dioses (The Arrival of the Gods)and La fundación (The Foundation) dating from 1971 and 1974, respectively, as well as, last but not least, in that other "Fantasia in Two Parts" entitled La detonación (The Detonation) of 1977, and centered, like the Goya play, round a figure from Spanish history. And these are only the most important pertinent texts that could be named. ${ }^{10}$

At any rate, blindness and deafness, on the one hand, and, on the other, hallucinations or comparable mental disorders comprise the experiences the Spanish playwright wants to convey - as symbols or allegories or images of human existence through his empathetic endeavors, which were doubt-less both prompted or provoked by Brecht and simultaneously directed against him. Still, even an insight into this hidden though firm and insoluble connection manifesting itself in Buero's dramatic and theatrical practice is not sufficient on any account. As a critic and theorist, too, the prolific Spaniard has since 1963-although in broad daylight, as it were - undoubtedly occupied himself with the German, and tried to grapple with the Brechtian texts and productions and, above all, theoretical utterances. Regrettably, I cannot go into any details of this rich and multifaceted process of literary reception extending over decades; what I can do, however, is

${ }^{10} \mathrm{Cf}$. Victor Dixon, "The 'Immersion-Effect' in the Plays of Antonio Buero Vallejo," in Drama and Mimesis. Ed. James Redmond (Cambridge, 1980) 113-37, esp. $118 \mathrm{ff}$. proffer a small selection of quotations plus the necessary elucidations.

The phenomenon in itself, i.e., Buero's technique of forced and absolute empathizing, is certainly rigorous enough, nonetheless, I daresay; the slogan accompanying it "immersion effect" is even more rigid: (efecto de inmersión). Coined and first employed by the critic Ricardo Doménech in his book El teatro de Buero Vallejo of 1973, it was propounded in a much-cited passage which runs:

For lack of another and better name, we suggest for those inventions [literally, hallazgos, meaning discoveries or findings] the designation 'immersion effects' (the word 'identification' would prove to be not sufficiently comprehensive, for what we are faced with is a sort of identification raised to its most radical extreme). ${ }^{11}$

This, assuredly, was the right name at the right time. For not only did the bulk of Buero criticism and scholarship accept Doménech's suggestion almost instantaneously, but so did, the dramatist himself, most willingly, publicly pronouncing his blessing, so to speak. As early as spring 1974 , he declared:

Doménech has called those effects, which I consider my very own contribution [to modern theater], 'immersion effects,' thereby coining a designation which might well

\footnotetext{
${ }^{11}$ Ricardo Doménch, El teatro de Buero

Vallejo : Una meditación española (Madrid, 1973) 49.
} 
turn out to be their definitive name. $^{12}$

The inference that the Spaniard's "very own contribution" (aportación propia) was basically conceived as, and imposingly constitutes in all events, a counterconception, outright and determined, of the Brechtian concept and technique of alienation is irrefutable and can be corroborated and documented nearly at will. And mustn't it give us pause in this connection that Buero and his fellow countrymen prefer to render the term Verfremdung as "distanciation"? Anyhow, whether singled out and expressly mentioned - as, for example, in the two essays "A propósito de Brecht" and "Brecht dominante, Brecht recesivo" as well as in apropos statements and letters ${ }^{13}$ or whether merely, but every so often,

${ }^{12}$ Cf. José Monleón, "Entrevista con A. Buero

Vallejo: (Buero: De la repugnante y necesaria viloencia a la repugnante e inútil crueldad, Primer Acto 167 (April 1974) : 4-13.

${ }^{13}$ Cf. Antonio Buero Vallejo, "A propósito de Brecht," Insula 200-01 (July/August 1963) :

$1+14$; id., "Brecht dominante, Brecht recesivo, "Vorick 20 (November 1966) : 12 f.; id., "[Respuesta de Antonio Buero Vallejo a una] encuesta... sobre la vigencia del teatro del autor alemán [=Bertolt Brecht] en su setenta y cinco aniversaric," Primer Acto 156 (May 1973) : 20. Also, compare Buero's speech, given in Tübingen, and entitled "De mi teatro," Romanistisches Jahrbuch 30 (1979) : 217-27, as well as the monographs by Robert $\mathrm{L}$. Nicholas, The Tragic Stages of Antonio Buero Vallejo (Chapel Hill, 1972) and Emili Bejel, Buero Vallejo : Lo moral, lo social y 10 metafisico (Montevideo, 19720), both of which contain valuable epistolary testimonies by the Spanish playwright. For an overall survey, see my Einiberischer "Gegenentwurf"? passim. referred to by implication, Bertolt Brecht has always been the one and only one at whom, however respectfully, Buero's critical endeavors and, ultimately, scenic activities have been aimed.

Thus, our conclusion seems to be unequivocal. No matter how genuinely dialec-tical the process of Buero's Brecht re-ception may appear, nevertheless: its result impresses itself on us as entirely undialectical to wit, as the stern and unmediated opposition of the Spanish immersion effect and the German alienation effect, or the I-effect and the A-effect (the $V$-Effekt in the original). However, this seemingly safe and sound conclusion is deceptive. Firstly, already the critical and polemical appropriation of the German playwright by the Spaniard is not at all devoid of grave misunderstandings, shortcomings, and internal contradictions; secondly, that which resulted in the long run was anything but an unbridgeable gap, an aesthetic and dramaturgical opposition. Not just Buero himself but also the more insightful among his chroniclers or adherents and advocates could not help perceiving and, finally, admitting this. For instance, the British critic Victor Dixon stated in no uncertain terms concerning the lighting in that crucial scene from In the Burning Darkness:

The impact of this slow blackout is undeniable, especially in the context of the dialogue it accompanies; but to the fastidious spectator it may seem an 'artificial device.'... En la ardiente oscuri$\mathrm{dad}$, for all its metaphysical implications, adheres to the conventions of naturalistic illusionism; all its other light and sound effects are explained with careful regard for realism. By contrast, the blinding 
of the audience in act III is an alienating intrusion by the author. ${ }^{14}$

The same fundamental observation and conclusion, according to which spots of Brechtian alienation (or distanciation) pop up right in the midst of the most accomplished feats of Buerian immersion, holds true, in the last analysis, for the fervent Spaniard's oeuvre in its entirety. The manifold, most artful as well as most artificial, deception tactics, designed to bring about the total empathy of the spectators, are imbued with so open, so stark, so showy a theatricality as to prevent the audience except for some fleeting moments at best-from getting lost in the minds and senses of the onstage characters; rather, the spectators are wide awake or will very soon become so again - and therefore remain fully conscious both of themselves and of the respective theatrical event, which admittedly is, as a rule, brilliant. Nearly every such device, in a word, is being unmasked all by itself to a certain extent: Buero's I effect, secretly and unbeknownst to him, turns into an A-effect of sorts, or else it enters into a peculiar yet, now as ever, highly efficient combination with those overpowering Brechtian stage inventions he intends to replace.

And there are still other pertinent traits and traces that can be disentangled from the Spaniard's allegedly un- or even antiBrechtian writings. As early as 1963 , for example, we hit upon a lapidary thesis,

\footnotetext{
${ }^{14}$ Dixon, "The 'Immersion-Effect' " 118 (my emphasis); compare also Marion P[eter] Holt, The Contemporary Spanish Theater (19491972) (New York, 1975) 112.
}

Brechtian through and through, which decrees that the theater must by no means "lull the audience to sleep"; on the contrary, it must relentlessly "arouse" and "disturb" the spectators (el teatro no debe adormecer, sino despertar). ${ }^{15}$ To be sure, this is chiefly meant in an existential, metaphysical, or ontological sense; on the other hand, it likewise betrays a solid mixture of sociopolitical criticism. Not without reason, and in the very same essay, did Buero insist on the "social responsibility of the theater." Nor does his dual statement, being a confession as well as a demand, for its part constitute an isolated case. Even a full decade later, the Spaniard, frank and unabashed, declared that Brecht's oeuvre signifies an "enormous progress" (paso enorme) with regard to the playwright's and the theater's task, which consists, he maintained, in tearing up the web of lies that veils the true state of society, and in critically laying bare its real conditions (de revelar críticamente la realidad social). ${ }^{16}$ However, as we have to reply at once, doesn't any such brusque unveiling and shocking exposure possess, by definition, an indubitably didactic function (and, by that token, something for which Buero was wont to reproach Brecht)? ${ }^{17}$ Small wonder, then, if one has long since begun, in the Spaniard's own camp, to refer to his political and social didacticism equally as matter-offactly as to his metaphysical or existential revelations and instructions. Indeed, the audience cannot help absorbing - thus Dixon again-a veritable "message," learn-

${ }^{15}$ Cf. Buero, "A proposito de Brecht" 1.

${ }^{16}$ See the "Encuesta" of 1973 listed in n. 12 above.

17 For details, see my Ein iberischer

"Gegenentwurf"? passim. 
ing a veritable "lesson which is both sociopolitical and ontological." ${ }^{18}$ And I could easily continue for quite a while in the same or a similar vein. Without fail, Buero Vallejo

has... reconciled with remarkable skill the Brechtian concept of alienation with the boldest dramatic signature of his own theatre: the immersion-effect.

Thus Holt in retrospect. ${ }^{19}$ Or to adduce the laconic formulation of the Spaniard himself, which is seemingly arbitrary at first sight, but which on closer scrutiny proves most eloquent all of a sudden: "Brecht and Artaud can be reconciled with each other" (Brecht y Artaud son harmonizables) ${ }^{20}$ What Buero thereby wants to impart is, of course, the admission of his very own accomplishments: it was he, no question about it, whose drama and theater have achieved this improbable reconciliation, or even harmonization. Granted, whether such summary assertions will be tenable and convincing without reservation must still be left undecided, but there cannot be the slightest doubt that Antonin Artaud's "theater of cruelty" - seldom realized in performance, yet all the more wildly proclaimed and prophesied by him - is most intimately related to, and entwined with, Buero's overall procedure... or, at the very least, his most typical, most intensive, most consequent and

\footnotetext{
${ }^{18}$ See Dixon, "The 'Immersion-effect' " 131.

${ }^{19}$ Thus Holt in his introduction to Buero-

Vallejo [sic], Three Plays xx.

${ }^{20}$ Antonio Buero Vallejo, Tres maestros ante

el público (Valle-Inclár Valázques, Lorca)

(Madrid, 1973) 163.
}

unremitting immersion effects. The following three quotations, which belong to the very essence of the Artaudian teachings as put forth in the Frenchman's speeches and manifests, and assembled in his volume Le Théâtre et son double (The Theater and Its Double) in particular, definitely need no explanation whatsoever, I trust, in that respect:

It is in order to attack the spectator's sensibility on all sides that we advocate a revolving spectacle [un spectacle tournant] which, instead of making the stage and auditorium two closed worlds, without possible communication, spreads its visual and sonorous outbursts [éclats] over the entire mass of the spectators. ${ }^{21}$

A direct communication will be reestablished between the spectator and the spectacle, between the actor and the spectator, from the fact that the spectator, placed in the middle of the action, is engulfed and physically affected by it [enveloppé et sillonné, i.e., virtually 'furrowed'].

And after an instant the magic identification $\left[l^{\prime}\right.$ identification $m a-$ gique] is made: WE KNOW IT IS WE WHO WERE SPEAKING.

21 Antonin Artaud, The Theater and Its

Double. Trans. Mary Caroline Richards (New York, 1958) 86; id., Oeuvres complètes (Paris, $1956 \mathrm{ff} .4: 103$. As for the following quotes from the French maniac's writings, see Artaud, The Theater and Its Double 96, 67, 93, 87, on the one hand, and, on the other, id., Oeuvres completes 4: 115, 80, 111, 104. 
Really, what could be more Buerian, more fit for the Spaniard's innermost intentions and practices?

Yet even quite concrete and detailed, indeed near literal, correspondences can be shown to exist between Buero Vallejo and Antonin Artaud. For doesn't the curt prescription of "sudden changes of light" ([des] changements brusques de la lumière) so as to create immediate empathy, or absolute identification, look like a stage direction not just for one or two Buerian plays but for a whole bunch thereof? Still, what the Frenchman demands is yet more: namely, "[des] éclats visuel et sonores," that is to say, exactly that which he has elsewhere labeled as a"space thundering with images and crammed with sounds" (espace tonnant $d^{\prime}$ images, gorgé de sons). And this, no doubt, is in turn a striking report avant la lettre of the monstrous happenings at the end of Buero's Goya play where, according to his stage directions, "the entire house" (la sala entera) has to be roared through by a virtual "hurricane" of earsplitting din and raging voices while at the same time, gigantic and dazzling, a huge projection of Goya's painting Witches' Sabbath (Aquelarre) emerges in the background. ${ }^{22}$ But that $E l$ sueño de la razón should come closest to the Artaudian concept seems to be only logical, after all, in view of those massive and almost unbearable light and sound effects unleashed, to top it off, when the

22 See Antonio Buero Vallejo, El sueño de la razón: Fantasia en dospartes (Madrid, 1970) 106: "... la confusión de voces avanzcomo un huracán sobre la sala entera, al tiempo que se va la luz y brilla en el fondo, bajo la ensordecedora algarabia, la agigantada pintura del 'Aquelarre'. " royal henchmen have broken into the painter's home, demolishing it, jeering and brutally maltreating him, and raping his woman, Leocadia, while forcing him to watch. Such, if anything, is authentic "théâtre de la cruauté" as not even the Frenchman himself could have envisioned it more genuinely. However, basically the selfsame procedure and, of course, deepseated aim apply mutatis mutandis to all or, at any rate, the vast majority of the Spaniard's pieces. His endeavors after total immersion reveal themselves - and he frankly admitted it - as always being of a both psychic and physical nature. ${ }^{23}$ To all intents and purposes, then, Antonio Buero Vallejo's work has been influenced and indelibly molded not only by Bertolt Brecht but by Antonin Artaud as well. The Goya drama culminating in a cruel witches' Sabbath (to return to it for a moment in order to round off my argument) constitutes, as I just intimated, the most Buerian of Buero's plays - and it is precisely this drama which has been prefigured, and verbatim to boot, by the Frenchman, who recommended "certains Sabbats de Goya" as fitting means of theatrical expression as early as $1993 .^{24}$ Since the letter in question has, moreover, been inserted in Le théatre et son double, must we not assume that the Spanish playwright borrowed the cue for his most characteristic and expressive scene from none other than Artaud?

Let me break off at this juncture and merely add a few general remarks in conclusion. Phyllis Zatlin, with whom we

\footnotetext{
23 Id., "De mi teatro" 220.

${ }^{24}$ Cf. Artaud, Oeuvres complètes 4: 144;

id., The Theater and Its Double 120.
} 
started out, ends her informative survey with the confident assurance:

Until the memory of the Franco era fades away and complacency sets in, Brecht will continue to be a symbol of freedom and will find a welcome place on the Spanish stage. (64)

In 1990, when Zatlin's article was published, this may, supposedly, still have been the case. Yet how about nowadays? Hasn't the literary climate, in Spain as elsewhere, changed rather drastically in the meantime? Primer Acto, for instance, the erstwhile flagship of Spanish Brechtianism, didn't feature a single article or essay dealing with the German in its 1991 and 1992 volumes. Neither does his name appear in a "Manifesto 'Por la defensa de la cultura' " nor even in a roundtable on "Politica teatral' or, for that matter, in a portrait of Buero Vallejo which, by the way, doesn't mention the much-debated I-effect, either. Instead, Fernando Arrabal was allowed to present his eulogy on the elective Frenchman from Russia, Arthur Adamov, an embarrasing piece of journalism that extols the stale and shopworn theater of the absurd, including Eugene Ionesco, while trying to lash out against Brecht with a barrage of contentions teeming with misunderstandings, inaccuracies, plain errors, and sheer nonsense. ${ }^{25}$ Hence, could it be that all this signals a total turnabout, a rash and wholly unexpected rejection of the German playwright and theorist in latter-day Spain? Or is it the first indication of a novel and, indeed, fashionable reception of his work along the lines of, say, Elizabeth Wright's

\footnotetext{
${ }^{25}$ For details, see Grimm, Versuche zur europä ischen Literatur 232, n. 41.
}

programmatic and highly questionable brochure Postmodern Brecht ? $^{26}$

In any case, that Buero's playwriting and theorizing have to be seen and located in an aesthetic and dramaturgical context far transcending the confines of Spanish letters ought to be self-evident. They are, in fact, an integral part of a far-reaching development in world literature and world theater which began to sprout as early as 1872, with Friedrich Nietzsche's famous treatise The Birth of Tragedy from the Spirit of Music, and which may aptly be defined, both pithily and exhaustively, as a conflict yet also mediation invloving a Dionysian (and metaphysical, existential, or ontological) theater of cruelty best represented by Artaud, and a Socratic-not, however, Apollinian - epic and didactic theater of alienation bent on social criticism, and best represented by Brecht. In other words, the dramatic oeuvre of Antonio Buero Vallejo, who is, without fail, the greatest Spanish playwright since Federico Garcia Lorca, must be placed side by side and on a par with dramas such as Marat/Sade by Peter Weiss, Mauser or Hamletmaschine by Heiner Muller, Equus by Peter Shaffer, and Kaspar by Peter Handke, all of whose authors, each in his own way, and either wittingly or unwittingly, combine and amalgamate the rich Artaudian as well as Brechtian legacies, which for their part derive, no matter how contradictorily, from the sovereign Nietzschean heritage that ushered in, as did the

${ }^{26}$ Cf. Elizabeth Wright, Postmodern Brecht: A

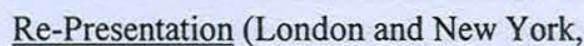
1989); also, see my review article "Brecht-auf den Postmodernismus gekommen, " Monatshefte 82 (1990) : 73-80. 
simultaneous advent of naturalism, modern drama and theater in the early $1870 \mathrm{s.}^{27}$

These influential plays, like most of the Buerian pieces relevant here, were written, printed, and staged before or during the 1970s. Does that perhaps mean that the century-old development I have sketched, ever so rapidly, is drawing to a close, or has already tapered off, just as, again perhaps, the impact of Brecht on Spain or even that of her native Buero has dwindled Avowedly, I am not very fond of the newfangled term 'postmodernism,' but I might now be persuaded to take it up for a change. Doesn't it seem, I might concede, that the epoch of modernism in drama and in the theater is over, and that something postmodern is, or has been, developing in its stead? And if so, I might continue to ask, is so sweeping a judgment in truth applicable to Western culture as a whole or possibly, who knows, worldwide, or is it restricted (which is quite unlikely) solely to Spanish literature? However, any sound and satisfactory answers to such questions would require, at least a couple of investigations and sizable disquisitions of their own.

${ }^{27}$ Cf. Reinhold Grimm, "The Hidden Heritage: Repercussions of Nietzsche in Modern Theater and Its Theory, "Nietzsche-Studien 12 (1983) 355-71; rept. In my volume Echo and Disguise: studies in German and Comparative Literature (Frankfurt am Main [etc.], 1989) 61-78. In addition, see my "Zwischen Raserei und Ratio: Deutsche Dramatikseit 1870 in weltliterarischem $\mathrm{Zu}$-sammenhang," $\mathrm{LiLi}$ 24.94 (1994) : 127-34. 